\title{
Preparation and characterization of monoclonal antibodies against neoplastic hemocytes of Mytilus edulis (Bivalvia)
}

\author{
D. Noël ${ }^{1}$, V. Boulo ${ }^{1}$, D. Chagot ${ }^{1}$, E. Mialhe ${ }^{1}$, F. Paolucci ${ }^{2}$, C. Clavies $^{2}$, E. Hervaud $^{2}$, \\ R. Elston ${ }^{3}$ \\ 1 IFREMER, Laboratoire de Pathologie et de Génétique des Invertébrés Marins, B.P. 133, F-17390 La Tremblade, France \\ 2 SANOFI, Service Immunodiagnostic, rue du Professeur Blayac, F-34082 Montpellier, France \\ ${ }^{3}$ Battelle, Marine Sciences Laboratory, 439 W. Sequim Bay Road, Sequim, Washington 98382, USA
}

\begin{abstract}
Mytilus edulis develop progressive and fatal hemocytic neoplasia. We have generated monoclonal antibodies using neoplastic hemocytes from highly infected individuals collected from Puget Sound in Washington State (USA). Twenty-seven monoclonal antibodies against neoplastic cell antigens were obtained. Specificity of 2 purified antibodies, $14 \mathrm{~F} 1$ and $16 \mathrm{G} 10$, was demonstrated by immunofluorescence when incubated with neoplastic hemocytes, whereas these antibodies did not react with normal cells. This specificity was confirmed by immunogold labelling and electron microscopic visualization. The technique permitted localization of the epitopes recognized by the monoclonal antibodies on the plasma membrane. These monoclonal antibodies are suitable reagents for establishment of immunoassays for diagnosis and quantification of hemic neoplasia in the mussel.
\end{abstract}

\section{INTRODUCTION}

Hemic proliferative disorders have been reported from at least 15 species of bivalve molluscs around the world (Farley \& Sparks 1969, Brown et al. 1977, Balouet et al. 1983, Twomey \& Mulcahy 1984, Peters 1989). The condition has been intensively studied in both the clam Mya arenaria (Cooper et al. 1982) and the mussel Mytilus edulis, in which it is considered to be a neoplastic process (Elston et al. 1988a). Hemocytic neoplasia ( $\mathrm{HCN}$ ) in $M$. arenaria is transmissible and results from a retrovirus infection (Oprandy et al. 1981) which is inducible by bromodeoxyuridine (Oprandy \& Chang 1983). In $M$. edulis, the condition is characterized by the proliferation of enlarged circulating hemocytes with a high nucleus-to-cytoplasm ratio. Mitotic figures are common in affected cells which appear to replace both normal hemocytes and other tissues in the terminal stage of the disease. An important recent observation was that, although hemic neoplasia is progressive and fatal in most $M$. edulis from a specific field population, a certain proportion of individuals undergo remission of the disease (Elston et al. 1988a). Furthermore, Elston et al. (1988a) presented histological evidence indicating that remission resulted from the recognition of neoplastic cells by morphologically normal host hemocytes. The condition is also transplantable with whole cells and transmissible with cell-free homogenates but the etiologic agent remains unknown (Elston et al. 1988b). Monoclonal antibodies have been used in vertebrate oncology to characterize specific cellular antigens as well as for the establishment of immunoassays to diagnose and quantify cancer and other diseases (Delsol et al. 1989). Moreover, they are useful tools for studying the origin of neoplastic cells. In this paper, we report the preparation of monoclonal antibodies specific for neoplastic hemocytes in $M$. edulis.

\section{MATERIAL AND METHODS}

Organisms. Infected mussels were obtained from Puget Sound in Washington State (USA). Healthy individuals were collected from Marennes-Oléron Basin (France). Mussels were identified as Mytilus edulis by morphologic features. However, recent population studies utilizing isozyme analyses suggest that previ- 
ously accepted species designations are not universally accepted (McDonald \& Koehn 1988).

Hemocytes. Mussels were bled through the posterior adductor muscle. Blood samples (500 to $1500 \mu \mathrm{l})$ were withdrawn into separate syringes through 23 gauge needles. A drop of hemolymph from each sample was immediately deposited on a glass slide and examined using inverted differential interference contrast microscopy. Neoplastic cells were identified by their relatively large size, and by failure to spread and attach to glass microscope slides. Whole hemolymph samples were stored at $-20^{\circ} \mathrm{C}$.

\section{Immunization protocols.}

Active immunization: Four Balb/c mice were immunized by initial intravenous injections $(300 \mu l)$ of neoplastic cell suspensions $\left(1.2 \times 10^{+}\right.$cells $)$diluted with 2 parts of sterile distilled water to 1 part of cell suspension in order to obtain a solution which was isosmotic to mouse serum. Subsequently, 4 similar injections were made at $2 \mathrm{wk}$ intervals.

Three weeks after the last immunization, serum titers were estimated for all mice using normal and neoplastic cells by the Radio Immunological Assay method (RIA) described below.

Passive immunization: Specific immune sera against normal hemocytes were prepared by making 4 successive intravenous or intraperitoneal inoculations of normal hemocyte suspensions $(300 \mu l)$ containing ca 300000 cells each. These injections were made at $3 \mathrm{~d}$ intervals. One week after the last booster, mice were exsanguinated in order to recover the serum. These sera were pooled and incubated for $2 \mathrm{~h}\left(37^{\circ} \mathrm{C}\right)$ with neoplastic hemolymph which had been subjected to one freezing and thawing cycle in order to expose both internal and external epitopes of the cells. After subsequent centrifugation $(4000 \mathrm{~g}, 30 \mathrm{~min})$, the pellet was resuspended in $3 \mathrm{ml}$ of $0.2 \mathrm{M} \mathrm{NaCl}$. With this suspension, 4 intravenous inoculations $(300 \mu \mathrm{I})$ were performed on mice at $3 \mathrm{~d}$ intervals with the last injection made 1 mo before fusion.

Fusion protocol. For the 2 mice selected by the RIA method (see below), a last intraperitoneal booster $110^{\text {? }}$ cells in $300 \mu \mathrm{l}$ ) was made $3 \mathrm{~d}$ before fusion. The myeloma cell line P3-X63-Ag653 (653) was cultivated in RPMI 1640 (Gibco Laboratories) containing 10\% heat-inactivated fetal calf serum (FCS) and $0.2 \mathrm{M}$ glutamine (complete RPMI). Before the fusion, these cells were cultivated in complete RPMI supplemented by $0.13 \mathrm{mM}$ azaguanine, which is a lethal analog of hypoxanthine, in order to eliminate possible HGPRT $^{+}$ mutants in the culture. Spleen cells were fused with the myeloma cell line by a method adapted from French et al. (1986). Splenocytes and myeloma cells were washed and suspended in a serum-free medium (RPMI 1640). Two fusions, $A$ and $B$, were performed corresponding to mice respectively immunized according to active and passive protocols. Splenocytes from mouse A $\left(1.13 \times 10^{8}\right)$ and from mouse $B\left(1.56 \times 10^{8}\right)$ were centrifuged with myeloma cells (ratio 5 to 1$)(200 \mathrm{~g}, 10 \mathrm{~min}$, room temperature). Subsequently, $1 \mathrm{ml}$ of $40 \%$ polyethylene-glycol 1540 (Riedel de Haen AG, Seelze, Hannover, Germany) was added to the cell pellet dropwise over $30 \mathrm{~s}$ with gentle stirring. After $1 \mathrm{~min}$ at $37^{\circ} \mathrm{C}$, the cells were pelleted by centrifugation $(200 \mathrm{~g}, 90 \mathrm{~s})$ and incubated for another $2 \mathrm{~min}$ at $37^{\circ} \mathrm{C}$. The pellet was then diluted to $15 \mathrm{ml}$ by addition of serum-free medium (the first $6 \mathrm{ml}$ were added over $5 \mathrm{~min}$ ).

Cells were centrifuged for $10 \mathrm{~min}$ at $150 \mathrm{~g}$, resuspended in the medium containing $10 \%$ fetal calf serum in order to obtain $1.5 \times 10^{6}$ cells $\mathrm{ml}^{-1}$ and distributed $\left(0.1 \mathrm{ml} \mathrm{well}{ }^{-1}\right)$ into microculture plates containing macrophages as feeder cells ( 1 to $2 \times 10^{4} \mathrm{Balb} / \mathrm{C}$ peritoneal exudate cells $\left(0.2 \mathrm{ml}^{-1}\right.$ well $\left.{ }^{-1}\right)$. Nine plates were prepared for Fusion A and 12 for Fusion B. These conditions were considered a pre-cloning step. One day after fusion, hybridomas were selected in HAT medium (10 $\mathrm{mM}$ Hypoxanthine, $4 \times 10^{-7} \mathrm{M}$ Aminopterine, $1.6 \times 10^{-5} \mathrm{M}$ Thymidine). Four days and $7 \mathrm{~d}$ after fusion, $100 \mu$ l of the culture supernatant were removed from each well and replaced with HAT medium. The occurence of cultures with replicating hybridoma cells was determined every $2 \mathrm{~d}$ from 7 to $17 \mathrm{~d}$ after fusion by visual examination with an inverted phase contrast microscope.

Hybridoma screening procedure. Two screening tests were simultaneously used for each precloned hybridoma culture supernatant in order to estimate their relative activity against normal hemocytes (control test) and against neoplastic hemocytes (positive test). For each type of screening test, either normal or abnormal hemocytes (50 000 cells well ${ }^{-1}$ ) were seeded in microtiter plates (Millititer type GV, Millipore). These cells were concentrated and adsorbed by vacuum filtration on the porous membrane $(0.22 \mu \mathrm{m})$ which constituted the bottom of the well. After a wash with $0.5 \mathrm{M} \mathrm{NaCl}$ and vacuum filtration, the plates were dried at $37^{\circ} \mathrm{C}$.

The hybridoma culture supernatants $(50 \mu l)$ were tested using a RIA assay. They were placed into each well for incubation ( $1 \mathrm{~h}$, ambient temperature). After 5 washes (PBS), a goat anti-mouse IgG (Diagnostic Pasteur), labelled with ${ }^{125}$ by oxidation with chloramine $T$ (Butt 1984) and diluted in PBS with $0.5 \%$ BSA (Bovine Serum Albumin) to $2 \times 10^{6} \mathrm{cpm} \mathrm{ml}^{-1}$, was incubated in each well (100 $\mathrm{\mu l}$ well $^{-1}, 1 \mathrm{~h}$, ambient temperature). Following incubation and 5 washes with PBS containing $0.5 \%$ Tween 20 , the membranes of each well were removed and the radioactivity was measured with a gamma counter.

Cloning procedure. The selected hybridomas were cloned using the limiting dilution method. The super- 
natants were then tested using an enzymatic immunoassay (ELISA). Initial steps were the same as those previously described. Radiolabelled goat antimouse IgG was replaced by alkaline phosphatase conjugate (Biosys), diluted (1/4000) in immunofluorescence buffer (Diagnostic Pasteur). Following 7 washes with $0.2 \mathrm{M} \mathrm{NaCl}$ containing $0.05 \%$ Tween 20 , the substrate solution (1 $\mathrm{mg}$ nitrophenylphosphate $\mathrm{ml}^{-1}$ diethanolamine, $5 \%$ in distilled water, $\mathrm{pH} 9.8$ ) was incubated at $37^{\circ} \mathrm{C}$ for $1 \mathrm{~h}\left(200 \mu \mathrm{l}\right.$ well $\left.{ }^{-1}\right)$. Samples $(100 \mu \mathrm{l})$ were finally taken from each well and placed in polystyrene microplate wells in order to measure their optical densities at $405 \mathrm{~nm}$ using a microplate spectrophotometer.

Production and purification of MABs. The cloned selected hybridomas ( 3 to $5 \times 10^{6}$ cells) were injected intraperitoneally into $\mathrm{Balb} / \mathrm{C}$ mice which had been injected $15 \mathrm{~d}$ before with $500 \mu \mathrm{l}$ of pristane. The ascitic fluids, which were positive 10 to $28 \mathrm{~d}$ after injection of the cells, were clarified by centrifugation and the monoclonal antibodies contained therein were purified by affinity chromatography with protein A-sepharose (Pharmacia). Isotypes of hybridoma culture supernatant antibodies were identified by the mouse monoclonal antibody isotyping kit (Amersham).

Indirect immunofluorescence. The specificity of each selected monoclonal antibody was tested by indirect immunofluorescence. For this purpose, hemolymph smears were prepared, air-dried and fixed by immersion in acetone $(10 \mathrm{~min})$. They could be used immediately or stored at $-20^{\circ} \mathrm{C}$. The assays were performed by overlaying the slides with a monoclonal antibody solution (specific or control) used at a final concentration of $25 \mu \mathrm{g} \mathrm{ml}^{-1}$ after dilution in immunofluorescence buffer (Diagnostic Pasteur). After a $15 \mathrm{~min}$ incubation period at ambient temperature in a moist chamber, the slides were washed 3 times with the previous buffer. They were then overlayed with FITCconjugated goat anti-mouse Ig serum (Diagnostic Pasteur), diluted in the same buffer $(1 / 100)$ containing $1 \%$ Evans-blue for $30 \mathrm{~min}$ at room temperature. The slides were examined for bright green fluorescent cells that were morphologically consistent with neoplastic hemocytes. Control antigens consisted of hemolymph smears prepared from healthy mussels. Control antibody preparations consisted in monoclonal antibodies against an oyster parasite Bonamia ostreae (Rogier et al. in press).

Preembedding ultrastructural immunohistochemistry.

Fixation: Hemocytes were fixed with $4 \%$ paraformaldehyde in $1 \mathrm{M}$ Sörensen buffer, $\mathrm{pH} 7.4$, for $60 \mathrm{~min}$ at $4{ }^{\circ} \mathrm{C}$. They were then washed 3 times in phosphatebuffered saline, $\mathrm{pH} 7.4$ (PBS: $8 \mathrm{~g} \mathrm{NaCl}, 0.2 \mathrm{~g} \mathrm{KCl}$, $1.44 \mathrm{~g} \mathrm{Na}_{2} \mathrm{HPO}_{4-2} \mathrm{H}_{2} \mathrm{O}, 0.23 \mathrm{~g} \mathrm{NaH}_{2} \mathrm{PO}_{4}, 1000 \mathrm{ml}$ distilled water), containing $0.02 \mathrm{M}$ glycine to quench free aldehyde groups (Slot et al. in press). Each rinse was followed by centrifugation $(200 \times \mathrm{g}, 10 \mathrm{~min})$.

Immunostaining: Centrifuged pellets were suspended in specific $14 \mathrm{~F} 1$ and $16 \mathrm{G} 10$ monoclonal antibody solutions, at a concentration of $25 \mu \mathrm{g} \mathrm{m}]^{-1}$ in PBS containing $1 \%$ BSA. In this and most steps, we used BSA in order to prevent background staining. Incubation lasted overnight at $4{ }^{\circ} \mathrm{C}$. Cells were then washed and pelleted 4 times in PBS containing $0.1 \%$ BSA. Labelling was performed with $15 \mathrm{~nm}$ colloidal gold particles prepared according to the tannic acid-citrategold procedure (Slot \& Geuze 1985), bound to protein A (Slot \& Geuze 1984) and purified by gradient centrifugation (Slot \& Geuze 1981). Just before use, protein Agold (PAG) was diluted in PBS containing $1 \%$ BSA in order to obtain an optical density of 0.15 at $520 \mathrm{~nm}$ wavelength. Hemocytes and PAG were incubated 45 min at room temperature, washed 4 times in PBS, and pelleted.

Electron microscopy: Cells were post-fixed in $1 \%$ osmium tetroxide to achieve adequate membrane preservation. After an additional wash in cacodylate- $\mathrm{NaCl}$ buffer, they were pre-embedded in agarose and processed for dehydration and embedding in Epon 812. Ultrathin sections were obtained using a diamond knife and double contrasted with aqueous uranyl acetate and lead citrate. The grids were viewed under a Jeol 1200 CX transmission electron microscope.

\section{RESULTS}

\section{Immunization of mice}

Following active or passive immunization (Springer 1983), the specificity of serum of each mouse was evaluated by the RIA method. These sera contained antibodies against both normal and neoplastic hemocytes. Regardless of which immunization protocol was used, all tested mice showed a greater immunoreactivity against normal cells than against neoplastic hemocytes (data not shown). However, one mouse (A) actively immunized, exhibited an immunologic activity against abnormal hemocytes at least comparable to the one against normal cells. Another mouse (B) immunized according to the passive protocol, was also retained for fusion due to its high reactivity against both normal and neoplastic hemocytes (Fig. 1).

\section{Hybridoma selection}

The immunofluorescence pattern obtained with polyclonal antibodies had previously revealed the presence of a majority of common antigens on both normal 


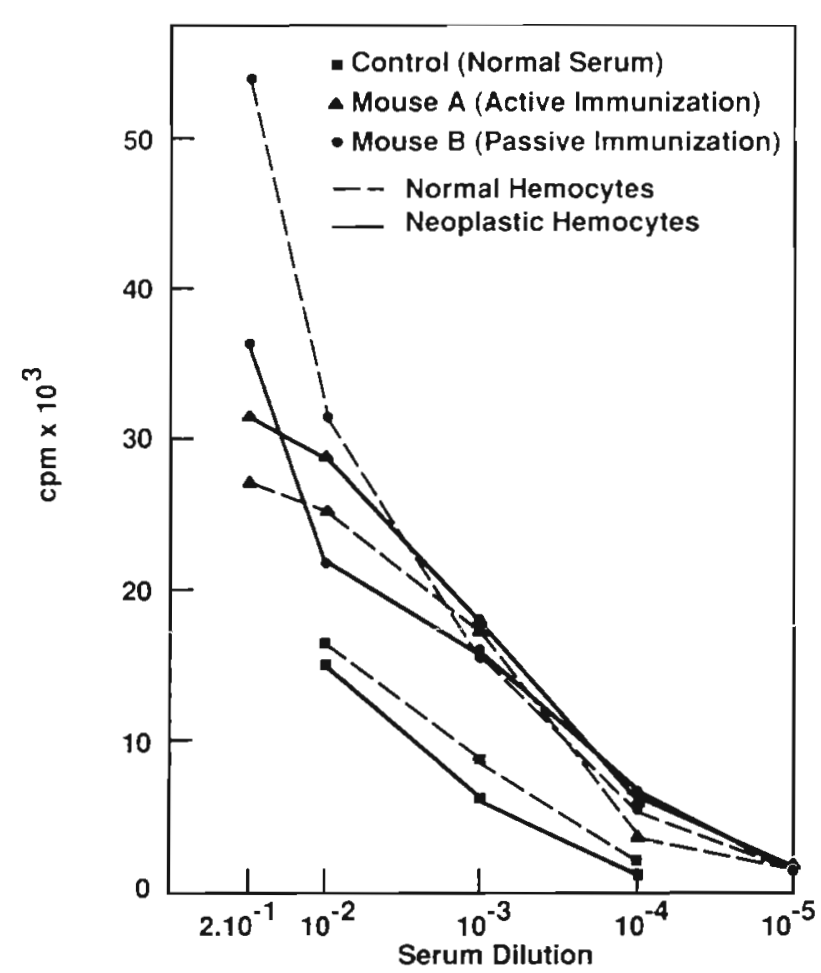

Fig. 1. Reactivity of serum of 2 mice (A and B) against normal and abnormal hemocytes, tested by the RIA method. cpm: count $\min ^{-1}$

and neoplastic hemocytes. Thus, in order to identify hybridomas producing specific antibodies for neoplastic cell antigens, a double screening test was performed. Specificity was determined comparing reactivity of the hybridoma supernatants with normal hemo- cytes to those reacting with antigens of abnormal cells. Based on a difference of $3000 \mathrm{cpm}$ between the signals obtained against these 2 kinds of normal or tumor antigens, 27 hybridomas were retained. A variability in the reactivity of hybridoma culture supernatants against transformed hemocytes is shown in Fig. 2 but for clearest representation, only 10 of them were selected for this figure. Most of the monoclonal antibodies specific for neoplastic hemocytes were obtained from Fusion $B$, that is after passive immunization.

\section{Cloning}

Comparison of the ELISA and RIA methods is given in Table 1. Although the ELISA method was less sensitive than the RIA method, it detected hybridomas showing a high activity against neoplastic cells and was thus selected for cloning in order to avoid use of radioactive isotopes. Two hybridomas, $14 \mathrm{~F} 1$ and 16G10, were selected and cloned because they showed the highest specific activities against abnormal cells (Fig. 2). Furthermore, when testing reactivity of the monoclonal antibodies after successive hybridoma culture supernatant dilutions, the results indicated a higher affinity of these 2 antibodies for their antigens than the other antibodies (Fig. 3A, B). Using the double screening ELISA method, 3 and 4 clones, respectively, were selected (Table 2). The monoclonal antibodies of clones 14F1-5E9 and 16G10-5B9 were then produced by the ascitic fluid method, described earlier and purified on protein A-sepharose. Their isotopes were both determined as IgG 1 .

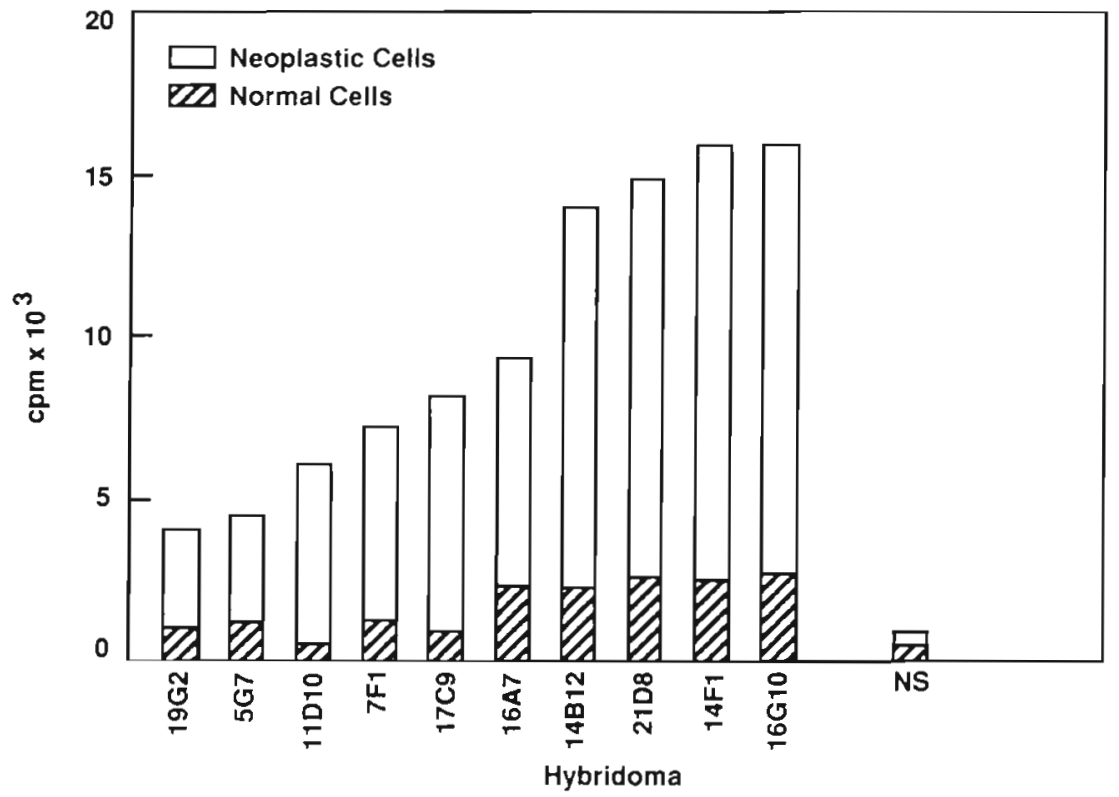

Fig. 2. Reactivity of some hybridoma culture supernatants against normal and neoplastic hemocytes, tested by the RIA method. NS: non-specific; cpm: count $\min ^{-1}$ 
Table 1. Comparison between the RIA and ELISA methods tested for some hybridoma culture supernatants

\begin{tabular}{|c|c|c|c|c|}
\hline \multirow{3}{*}{$\begin{array}{l}\text { Hybridoma } \\
\text { culture } \\
\text { supernatant }\end{array}$} & \multicolumn{4}{|c|}{ Specific activity } \\
\hline & \multicolumn{2}{|c|}{ By RIA (cpm) } & \multicolumn{2}{|c|}{ By ELISA (mDO) } \\
\hline & Normal cells & Neoplastic cells & Normal cells & Neoplastic cells \\
\hline $20 C 7$ & 467 & 494 & 225 & 166 \\
\hline 7 E5 & 411 & 4023 & 248 & 169 \\
\hline $19 B 7$ & 723 & 7020 & 208 & 246 \\
\hline $21 \mathrm{E} 6$ & 2572 & 13150 & 201 & 1373 \\
\hline $21 \mathrm{H} 10$ & 1178 & 15615 & 213 & 1085 \\
\hline
\end{tabular}

\section{Specificity of purified antibodies demonstrated by immunofluorescence}

Reactivity of each mouse immunserum was tested by immunofluorescence before fusion and has shown no specificity against the neoplastic cells. The monoclonal antibody specificity for neoplastic hemocytes was confirmed by indirect immunofluorescence. These antibodies did not produce any fluorescence when incubated with normal hemocytes either from healthy French mussels or healthy Puget Sound mussels whereas they strongly reacted with neoplastic cells. The bright green fluorescence was localized at the plasma membrane (Fig. $4 \mathrm{a}$, b). Using control monoclonal antibodies, no fluorescence was observed with either normal or abnormal hemocytes.

\section{Localization of the epitopes recognized by the monoclonal antibodies}

When ultrathin sections of specific antibody-PAG labelled hemocytes were examined, observations con-
Table 2. Specific activities of the cloned hybridomas, tested by the ELISA method

\begin{tabular}{|c|c|c|}
\hline \multirow{2}{*}{$\begin{array}{l}\text { Cloned } \\
\text { hybridoma }\end{array}$} & \multicolumn{2}{|c|}{ Specific activity (mDO) } \\
\hline & On normal cells & On neoplastic cells \\
\hline $16 \mathrm{G} 10-2 \mathrm{~F} 6$ & 250 & 691 \\
\hline 16G10-4F8 & 345 & 1005 \\
\hline $16 \mathrm{G} 10-5 \mathrm{~B} 9$ & 320 & 1308 \\
\hline $16 \mathrm{G} 10-2 \mathrm{~B} 9$ & 390 & 1396 \\
\hline $14 \mathrm{~F} 1-1 \mathrm{C} 9$ & 297 & 781 \\
\hline 14F1-3D11 & 302 & 813 \\
\hline $14 \mathrm{~F} 1-5 \mathrm{Eg}$ & 356 & 1077 \\
\hline RPMI & 394 & 379 \\
\hline
\end{tabular}

firmed the specificity of $14 \mathrm{~F} 1$ and $16 \mathrm{G} 10$ antibodies for neoplastic cells: gold particles were found only on abnormal hemocytes (Fig. 5a, b). No label was seen on normal cells when present in neoplastic mussels or on healthy hemocytes used as controls. The epitopes recognized by $14 \mathrm{~F} 1$ and $16 \mathrm{G} 10$ monoclonal antibodies were located at the plasma cell membrane. The gold

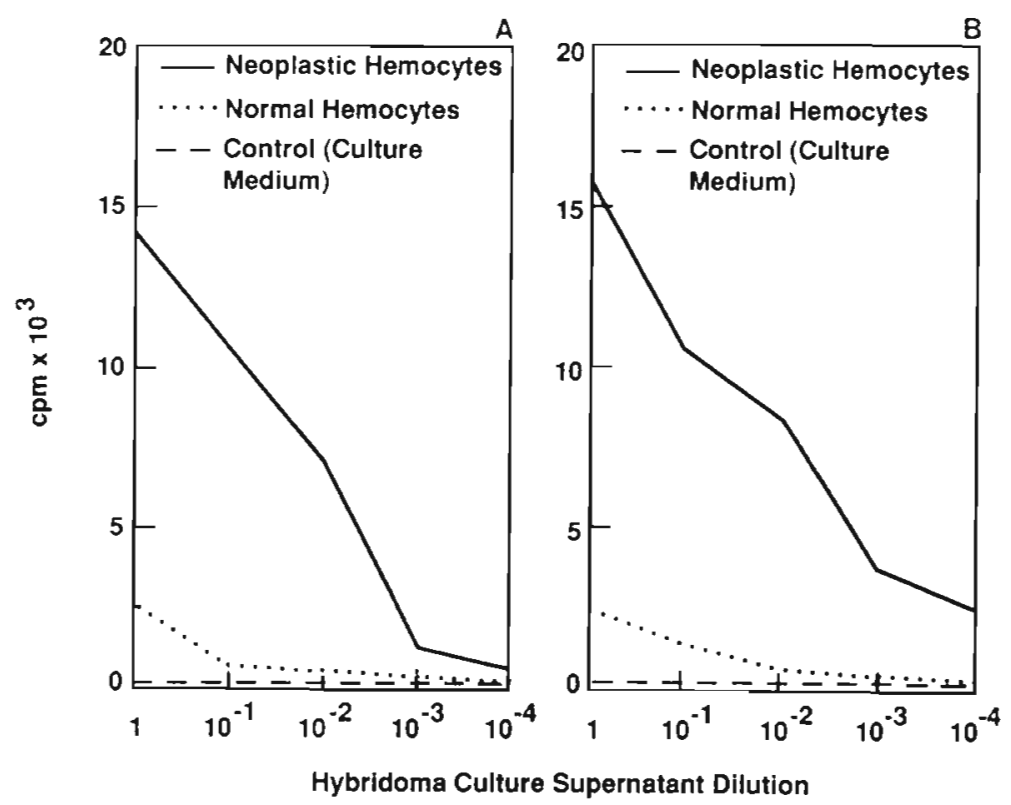

Fig. 3. Hybridoma culture supernatant reactivities against normal and abnormal hemocytes after serial dilutions, tested by the RIA method. (A) 16G10 monoclonal antibody; (B) 14F1 monoclonal antibody; cpm: count $\mathrm{min}^{-1}$ 

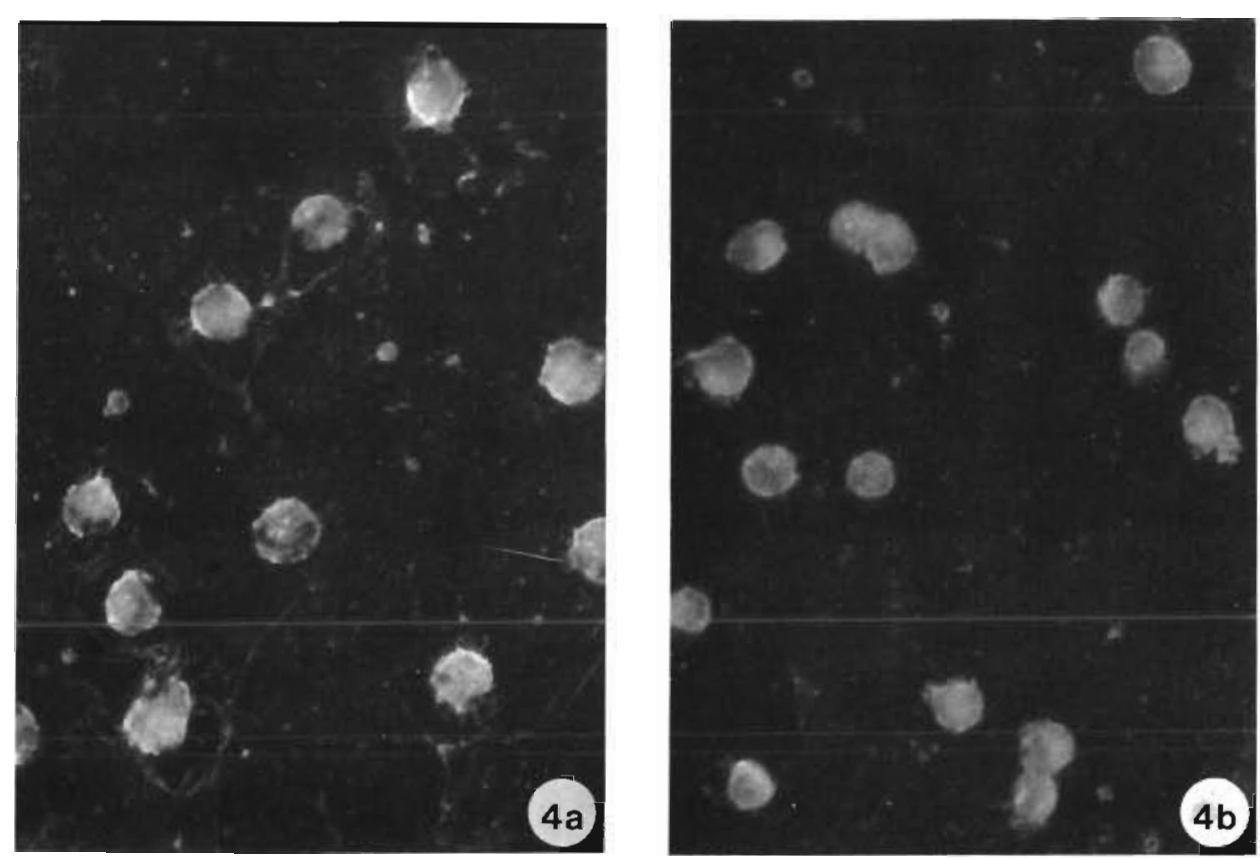

Fig. 4. Photomicrographs showing staining pattern of individual monoclonal antibodies against neoplastic hemocytes as revealed by indirect immunofluorescence assay. Note the specific cell membrane staining shown at the periphery of the cells. (a) Reactivity pattern of $14 \mathrm{~F} 1$ monoclonal antibody; (b) reactivity pattern of $16 \mathrm{G} 10$ monoclonal antibody

particles were sparsely distributed on the membrane and the labelling pattern was similar for the 2 antibodies.

\section{DISCUSSION}

The objective of these studies was to obtain monoclonal antibodies specific for neoplastic hemocytes. The main problems were the presence of common antigens on normal and abnormal cells and the difficulty in purifying sufficient amounts of specific proteins. In order to alleviate these problems, a passive immunization procedure, resulting in a masking of normal antigens on neoplastic hemocytes, was used before their inoculation into mice (Springer 1983). In addition to typical active immunization, the theoretical advantage of the passive immunization procedure was to enhance the immune response to host antigens not bound with antibodies, that is, specific neoplastic antigens. Initially, it appeared that the passive immunization was more efficient since most hybridomas specific for neoplastic cells were selected after fusion from a mouse immunized according to this protocol. However, it must be pointed out that at fusion day, this mouse also exhibited a high titer of antibodies against normal hemocytes. A second important step concerned the selection of specific hybridomas. In order to avoid the presence of several hybridomas in the same well, precloning, which consisted in seeding a large number of wells, was performed (Paolucci 1983). Screening was subsequently always performed in parallel on normal and abnormal hemocytes, adsorbed at a constant and identical number on Durapore membranes of Millititer plates (Millipore) (Dao 1985, Hessian et al. 1989). This method provides a better inter-well reproducibility compared to the more classical method of antigen adsorption on polystyrene plates with poly-L-lysine (Miosky et al. 1989).

Immunohistochemical methods, used by other investigators for screening monoclonal antibodies against neoplastic cells in Mytilus arenaria (Reinisch et al. 1983), appeared less practical for hybridoma supernatant screening compared to the RIA or ELISA methods. Moreover, alkaline phosphatase was preferred to peroxidase for antibody labelling, in order to prevent non-specific signals which could result from endogenous hemocyte activity (Chagot, 1989). Using this double screening protocol, hybridoma types were selected according to their specificity against normal and/or neoplastic hemocytes, although only results for hybridomas reacting with the neoplastic hemocytes are reported here.

The exclusive reactivity of purified monoclonal antibodies 14F1 and 16G10 with abnormal hemocytes was confirmed by indirect immunofluorescence. The specific localization of the recognized neoplastic epitopes on the cytoplasmic membranes by immunogold labelling and electron microscopic examination demonstrated another use of the monoclonal antibodies. These antibodies can also be used to study the 

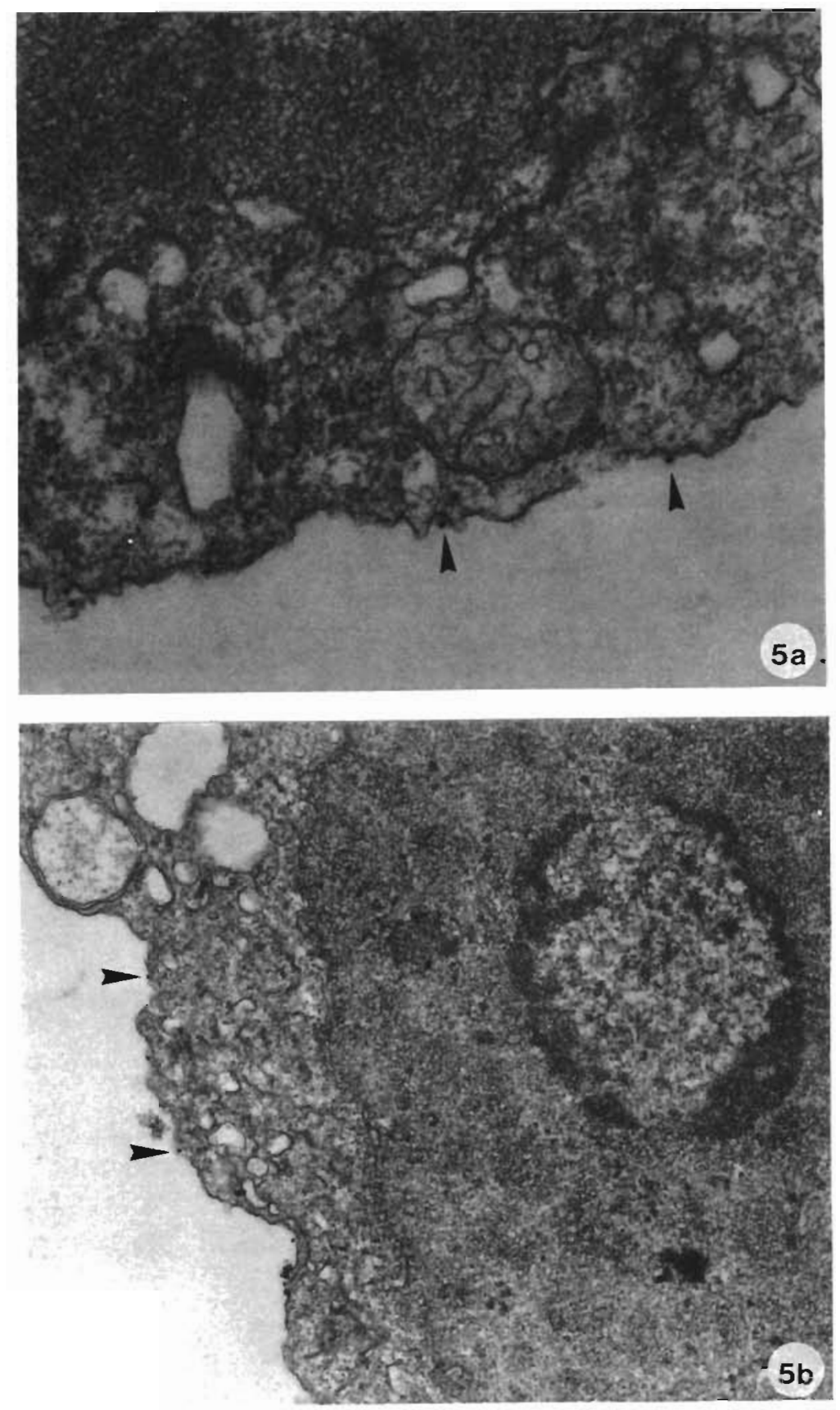

Fig. 5. Localization of epitopes on neoplastic cell cytoplasmic membranes (arrowheads) by use of immunogold labelling electron microscopy. (a) 14F1 monoclonal antibody pattern; (b) 16G10 monoclonal antibody pattern

role of neoplastic epitopes in tumor cell recognition by normal hemocytes, which apparently occurs in mussels undergoing remission (Elston et al. 1988a). Such involvement could be analyzed by using hemocyte primary cultures to look for an inhibition of recognition by normal hemocytes of tumor cells previously incubated with monoclonal antibodies (Mourton 1987, Chagot 1989). These specific antibodies can also be used to identify hematopoietic tissues by histological examination of early infected individuals. Furthermore, monoclonal antibodies can be used to study the transformation process and to characterize oncoproteins. The membrane localization of the epitopes could correspond to growth factor receptors (Deuel 1987) or tyrosine kinases. Isolation of mRNA coding for oncoproteins from neoplastic hemocytes and utilization of monoclonal antibodies to check their in vitro translation products will be useful in subsequent preparation 
of cDNA. Finally, a diagnostic method based on the monoclonal antibodies may be more convenient for epizootiological surveys than cytofluorometry (Elston et al. 1990) or immunoperoxidase histology (Smolowitz \& Reinisch 1986).

Acknowledgements. This work was supported in part by the U'S National Cancer Institute and the US Army Medical Research and Development Command under Grant Number SRC (8), 5 RO1 CA 44269-02.

\section{LITERATURE CITED}

Balouet, G., Poder, M., Cahour, A. (1983\}. Haenucyic parasitosis: morphology and pathology of lesions in the French flat oyster, Ostrea edulis L. Aquaculture 34: 1-14

Brown, R. S., Wolke, R. E., Salla, S. B., Brown, C. W. (1977). Prevalence of neoplasia in ten New England populations of the soft-shelled clam (Mya arenaria). Ann. N. Y Acad. Sci. 298: 522-534

Butt, W R. (1984). 2. Problems of iodination. In: Dekker, M. (ed.) Practical immunoassay, Vol. 19, p. 19-35

Chagot, D. (1989). Caractérisation morphologique et fonctionnelle des hémocytes d' Ostrea edulis et de Crassostrea gigas, mollusques bivalves. Etude in vitro de leurs interactions avec le protozoaire Bonamia ostreae (Ascetospora). Thèse E.P.H.E., Université de Montpellier, pp. 72

Cooper, K. R., Brown, R. S., Chang, P. W. (1982). The course and mortality of a hematopoietic neoplasm in the soft-shell clam, Mya arenaria. J. Invertebr. Pathol. 39: 149-157

Dao, M. L. (1985). An improved method of antigen detection on nitrocellulose: in situ staining of alkaline phosphatase conjugated antibody. J. Immunol. Methods 82: 225-231

Delsol, G., Woodman-Memetau, F., Caveriviere, P. (1989). Les anticorps monoclonaux à visée diagnostique en pathologie tumorale. Path. Biol. 37: 96-97

Devel, T F. (1987). Polypeptide growth factors: Roles in normal and abnormal cell growth. Ann. Rev. Cell Biol. 3: $443-492$

Elston, R. A., Drum, A. S., Allen, S. K. (1990). Progressive development of circulating polyploid cells in Mytilus with hemic neoplasia. Dis, aquat. Org. 8: 51-59

Elston, R. A., Kent, M. L., Drum, A. S. (1988a). Progression, lethality and remission of hemic neoplasia in the bay mussel Mytilus edulis. Dis. aquat. Org. 4: 135-142

Elston, R. A., Kent, M. L., Drum, A. S. (1988b). Transmission of hemic neoplasia in the bay mussel, Mytilus edulis, using whole cells and cell homogenate. Dev. Comp. Immunol. 12: 719-727

Farley, C. A., Sparks, A. K. (1969). Proliferative diseases of hemocytes, endothelial cells and connective tissue cells in molluscs. Comp. Leuk. Res. 36: 610-617

French, D., Fischberg, E., Buhl, S., Scharff, M. D. (1986). The production of more useful monoclonal antibodies. I. Modifications of the basic technology. Immunology Today 7 $344-346$

Hessian, P. A, Highton, J., Palmer, D. G. (1989). Development of an enzyme immunoassay for the quantitation of cellular antigen expression. J. Immunol. Methods 91: 29-34

McDonald, J. H., Koehn, R. K. (1988). The mussels Mytilus galloprovincialis and $M$. trossulus on the Pacific coast of North America. Mar. Biol. 99: 111-118

Miosky, D. L., Smolowitz, R. M., Reinisch, C. L. (1989). Leukemia cell specific protein of the bivalve molluscs Mya arenaria. J. Invertebr. Pathol. 53: 32-40

Mourton, C. (1987). Modèle d'étude in vitro de Bonamia ostreae (Ascetospora), parasite intrahémocytaire d' Ostrea edulis. Etude d'interactions cellulaires hote-parasite. Rapport de DEA, option Protistologie. Université de ClermontFerrand II, pp. 25

Oprandy, J. J., Chang, P. W., Pronovost, A. D., Cooper, K. R. Brown, R. S., Yat, V J. (1981). Isolation of a viral agent causing hematopoietic neoplasia in the soft-shell clam, Mya arenaria. J. Invertebr. Pathol. 38: 45-51

Oprandy, J. J., Chang, P. W. (1983). 5-bromodeoxyuridine induction of hematopoletic neoplasia and retrovirus activation in the soft-shell clam, Mya arenaria. J. Invertebr Pathol. 42: 196-206

Paolucci, F. (1983). Optimisation des techniques de préparation des anticorps monoclonaux par hybridation lymphocytaire. Rapport de DEA, option Immunologie, Université de Montpellier, pp. 95

Peters, E. C. (1989). Recent investigations on the disseminated sarcomas of marine bivalve molluscs. In: Fischer, W. F. (ed.) Disease processes in marine bivalve molluscs. American Fisheries Society, Special Publication, p. 74-92

Reinisch, C. L., Charles, A. M., Troutner, J. (1983). Unique antigens on neoplastic cells of the soft-shell clam Mya arenaria. Dev. Comp. Immunol. 7: 33-39

Rogier, H., Mialhe, E., Boulo, V., Clavies, C., Hervaud, E. Bachère, E., Grizel, H., Pau, B., Paolucci, F. (in press). Monoclonal antibodies against Bonamia ostreae (Protozoa Acetospora). Dis. aquat. Org.

Slot, J. W., Geuze, H. J. (1981). Sizing of protein A-colloidal gold probes for immunoelectron microscopy. J. Cell Biol. 90: $533-536$

Slot, J. W., Geuze, H. J. (1984). Gold markers for single and double immunolabelling of ultrathin sections. In: Polak, J. M., Varndell, I. M. (eds.) Immunolabelling for electron microscopy. Elsevier, p. 129-142

Slot, J. W., Geuze, H. J. (1985). A new method of preparing gold probes for multiple labelling cytochemistry. Eur. J Cell Biol. 38: 87-93

Slot, J. W., Weerkamp, A. H., Geuze, H. J. (in press). Localization of macromolecular components by application of the immunogold technique on cryo-sectioned bacteria. In: Mayer, F. (ed.) Methods in microbiology. Academic Press, London, Vol. 20

Smolowitz, R. M., Reinisch, C. L. (1986). Indirect peroxidase staining using monoclonal antibodies specific for Mya arenaria neoplastic cells. J. Invertebr. Pathol. 48: 139-145

Springer, T A. (1983). Monoclonal antibody analysis of complex biological systems. Combination of cell hybridization and immunosorbents in a novel cascade procedure and its application to the macrophage cell surface. J. Biol. Chem. 256: 3833-3839

Twomey, E., Mulcahy, M. F. (1984). A proliferative disorder of possible hemic origin in the common cockle, Cerastoderma edule. J. Invertebr. Pathol. 44: 109-111 